\title{
Litter Fall and Its Decomposition in Sapium sebiferum Roxb.: An Invasive Tree Species in Western Himalaya
}

\author{
Vikrant Jaryan, ${ }^{1}$ Sanjay Kr. Uniyal, ${ }^{1}$ R. C. Gupta, ${ }^{2}$ and R. D. Singh ${ }^{1}$ \\ ${ }^{1}$ Biodiversity Division, CSIR-Institute of Himalayan Bioresource Technology, Palampur, Himachal Pradesh 176061, India \\ ${ }^{2}$ Department of Botany, Punjabi University, Patiala, Punjab 147002, India \\ Correspondence should be addressed to Sanjay Kr. Uniyal; suniyal@ihbt.res.in
}

Received 28 August 2014; Revised 20 October 2014; Accepted 21 October 2014; Published 13 November 2014

Academic Editor: Béla Tóthmérész

Copyright (c) 2014 Vikrant Jaryan et al. This is an open access article distributed under the Creative Commons Attribution License, which permits unrestricted use, distribution, and reproduction in any medium, provided the original work is properly cited.

\begin{abstract}
Recognizing that high litter fall and its rapid decomposition are key traits of invasive species, litter fall and its decay in Sapium sebiferum Roxb. were studied in Palampur. For this, litter traps of dimension $50 \times 50 \times 50 \mathrm{~cm}^{3}$ were placed in under-canopy and canopy gap of the species. Litter fall was monitored monthly and segregated into different components. For litter decay studies, litter bags of dimension $25 \times 20 \mathrm{~cm}^{2}$ with a mesh size $2 \mathrm{~mm}$ were used and the same were analyzed on a fortnightly basis. Litter fall in both under-canopy and canopy gap was highest in November $\left(1.16 \mathrm{Mg} \mathrm{ha}^{-1} \mathrm{y}^{-1}\right.$ in under-canopy and $0.38 \mathrm{Mg} \mathrm{ha}^{-1} \mathrm{y}^{-1}$ in canopy gap) and lowest during March. Litter production in under-canopy and canopy gap was $4.04 \mathrm{Mg} \mathrm{ha}^{-1} \mathrm{y}^{-1}$ and $1.87 \mathrm{Mg} \mathrm{ha}^{-1} \mathrm{y}^{-1}$, respectively. These values are comparable to sal forest $\left(1.7 \mathrm{t} \mathrm{Cha}^{-1} \mathrm{y}^{-1}\right)$, chir pine-mixed forest $\left(2.1 \mathrm{t} \mathrm{Cha}^{-1} \mathrm{y}^{-1}\right)$, and mixed oak-conifer forest $\left(2.8 \mathrm{t} \mathrm{C} \mathrm{ha}^{-1} \mathrm{y}^{-1}\right)$ of the Western Himalaya. The decay rate, $0.46 \% \mathrm{day}^{-1}$ in under-canopy and $0.48 \% \mathrm{day}^{-1}$ in canopy gap, was also fast. Owing to this the species may be able to modify the habitats to its advantage, as has been reported elsewhere.
\end{abstract}

“Dr. R. D. Singh left for heavenly abode on 08/10/2014. We dedicate this paper to our beloved colleague"

\section{Introduction}

Litter refers to the dead material of plant origin that has been shed onto the ground. It may comprise leaves, bark, twigs, branches, inflorescence, seeds, and cones [1]. The decay of litter results in release of nutrients and its translocation. Thus, litter fall and its decomposition play an important role in ecosystem functioning [2-4]. Key ecological processes such as primary productivity, soil organic matter, mineralization of organic nutrients, nutrient cycling, and energy flow depend on the amount of litter fall and the rate of its decay $[5,6]$. Decay of litter, on the other hand, depends on the type of litter, its position, and water availability at the site [7]. High litter production and its faster decay lead to accelerated release of nutrients and thereby changes in soil characteristics [8]. This consequently has a bearing on the vegetation and soil microorganisms [8].

Studies on invasive species have shown high litter production and faster decomposition of the same in them $[9,10]$.
Thus, these are important traits of invasive species. Invasive species are nonnative species that have been intentionally or unintentionally introduced in an area outside their native range and are a reason for loss of native species and habitats $[11,12]$. Recent review [8], based on comparative account of pool sizes and flux rates of major nutrients in 56 invasive species, concluded that invasive species change the patterns of carbon and nitrogen cycle. Invasion by Myrica faya in Hawaii has considerably altered the ecosystem functioning [13]. Ashton et al. [14] in an experiment found that litter of invasive species decomposes and releases nitrogen faster than native species. Owing to this, an invasive species is able to modify the soil conditions to its advantage [14-16].

Recent studies have reported and modeled potential advancement of Sapium sebiferum Roxb., an invasive species, in the bio-rich Western Himalaya [17]. Sapium sebiferum (family Euphorbiaceae) is a native of China and is commonly called Chinese tallow tree. It was introduced in India in 1858 by the Britishers for economical and ornamental purposes 


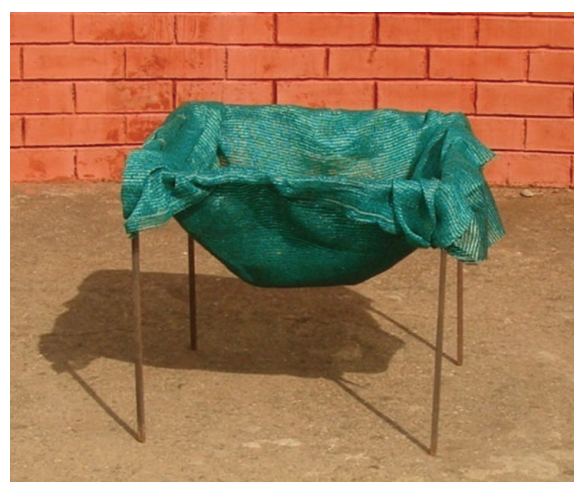

(a)

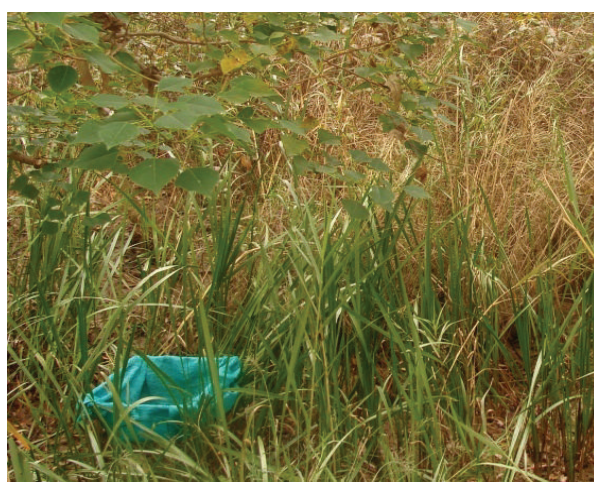

(b)

FIGURE 1: (a) Litter trap of dimension $50 \times 50 \times 50 \mathrm{~cm}^{3}$ and (b) its placement in the site.

TABLE 1: Rainfall and temperature pattern in Palampur.

\begin{tabular}{lccc}
\hline \multirow{2}{*}{ Month } & \multicolumn{2}{c}{ Temperature $\left({ }^{\circ} \mathrm{C}\right)$} & Rainfall $(\mathrm{mm})$ \\
& Minimum & Maximum & \\
\hline January & 3.53 & 15.22 & 65.00 \\
February & 6.56 & 16.40 & 248.20 \\
March & 10.22 & 22.61 & 45.30 \\
April & 13.13 & 25.18 & 90.70 \\
May & 19.25 & 31.37 & 120.40 \\
June & 18.82 & 28.66 & 389.60 \\
July & 19.88 & 26.35 & 483.00 \\
August & 19.22 & 25.55 & 872.20 \\
September & 17.43 & 26.25 & 252.40 \\
October & 13.27 & 25.42 & 34.80 \\
November & 9.87 & 22.81 & 1.80 \\
December & 5.77 & 19.48 & 6.00 \\
\hline
\end{tabular}

[18]. It is a deciduous tree species that rarely reaches $19 \mathrm{~m}$ in height. In Himachal Pradesh, it was first reported by Parker [19] from the Kangra Valley. The species now occupies $\sim 4611 \mathrm{~km}^{2}$ area in the state of Himachal Pradesh and at many places forms gregarious patches [17]. Considering its invasive status [20,21], wherein the species has been implicated in the loss of native flora and vegetation, studies on S. sebiferum in Himalaya become important. In our earlier studies we have documented the distribution characteristics [17], potential spread [22], and phenology [23] of S. sebiferum. The present study was, therefore, initiated to investigate the (1) seasonal litter fall patterns and (2) litter decay in the species.

\section{Materials and Methods}

The present study was conducted in Palampur that lies in the Kangra district of Himachal Pradesh. The area receives heavy rainfall ( $\sim 2500 \mathrm{~mm}$ annually) with maximum of it falling in the month of August (Table 1). The area reports minimum temperature in January while the maximum is during May (Table 1).
A permanent plot of $35 \times 25 \mathrm{~m}^{2}$ was set up at coordinates $32^{\circ} 06^{\prime} 21.5^{\prime \prime} \mathrm{N}$ and $76^{\circ} 33^{\prime} 29^{\prime \prime} \mathrm{E}$ at an altitude of $1300 \mathrm{~m}$ asl. Two sites, one "under-canopy" and the other "canopy gap," were selected inside the permanent plot for placing litter traps (Figure 1). Under-canopy refers to areas directly under the canopy of S. sebiferum while canopy gap refers to open areas between the canopies of the species.

Three litter traps, each of dimension $50 \times 50 \times 50 \mathrm{~cm}^{3}$, were placed in under-canopy and canopy gap. On the 15th of every month, litter was collected from the traps. This was then oven dried for $48 \mathrm{~h}$ at $60^{\circ} \mathrm{C}$ and weighed. Segregation of litter into inflorescence/seed, wood, and leaf was also done. This was, then, analyzed for monthly and finally annual litter fall patterns. It was calculated in $\mathrm{Mg} \mathrm{ha}^{-1} \mathrm{y}^{-1}$. Considering 50\% of the dry matter to be accounted for by carbon [24], results in $\mathrm{tCha}^{-1} \mathrm{y}^{-1}$ have also been presented.

For litter decomposition studies, senescing leaves of $S$. sebiferum were plucked and collected. These leaves were dried in an oven for $72 \mathrm{~h}$ at $60^{\circ} \mathrm{C} .10$ grams of the leaves was placed in each litter bag of dimension $25 \times 20 \mathrm{~cm}^{2}$ of mesh size $2 \mathrm{~mm}$. A total of 144 filled litter bags were placed in the undercanopy and canopy gap in replicates ( 72 bags in under-canopy and 72 in canopy gap) (Figure 2).

Every fortnight, 3 litter bags were randomly removed from each site. These bags were cleaned and placed in an oven for $48 \mathrm{~h}$ at $60^{\circ} \mathrm{C}$. After oven drying, the leaves were weighed. The decay rate was calculated as $\% \mathrm{day}^{-1}$ and the decay rate coefficient $(k)$ was calculated using the first-order exponential decay function [25-27]. The formula for the same is given as follows:

$$
y=e^{-k t}
$$

where $y$ is the percent mass remaining at a time point and $t$ is the time elapsed since the beginning of litter decomposition experiment (days).

\section{Results}

3.1. Litter Fall. Litter fall, both in under-canopy and in canopy gap, slowly increased after March and recorded the highest values in November $\left(1.16 \mathrm{Mgha}^{-1} \mathrm{y}^{-1}=0.58 \mathrm{tCha}^{-1} \mathrm{y}^{-1}\right.$ 


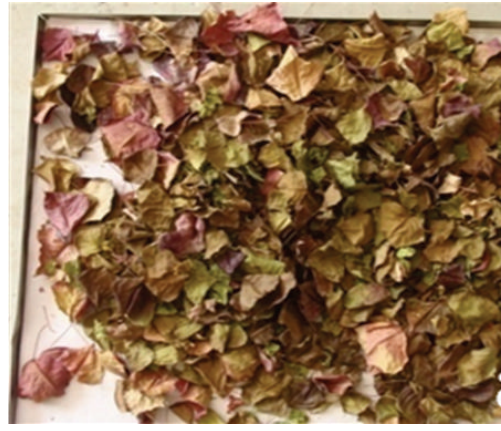

(a)

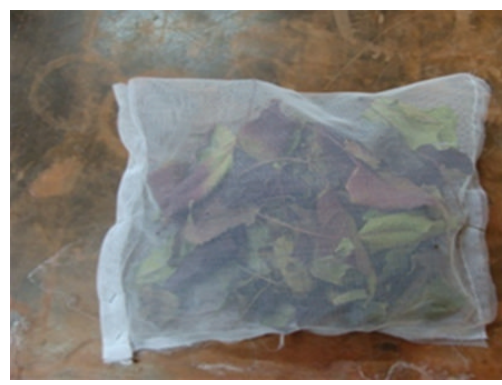

(c)

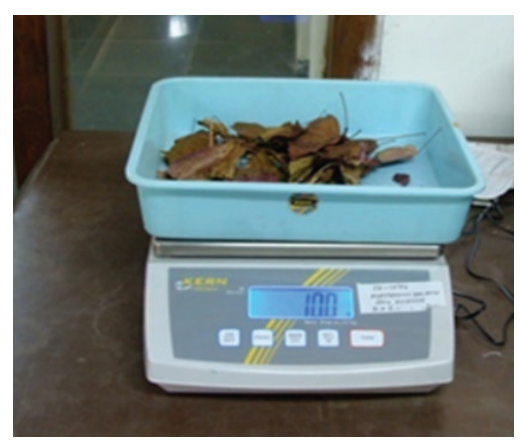

(b)

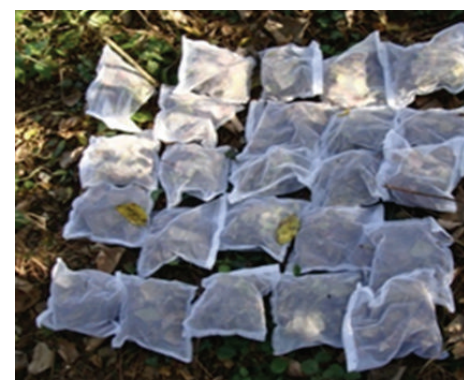

(d)

Figure 2: (a) Oven dried senescing leaves, (b) $10 \mathrm{~g}$ of leaves weighed, (c) litter bags of dimension $25 \times 20 \mathrm{~cm}^{2}$, and (d) litter bags placed in the permanent plot.

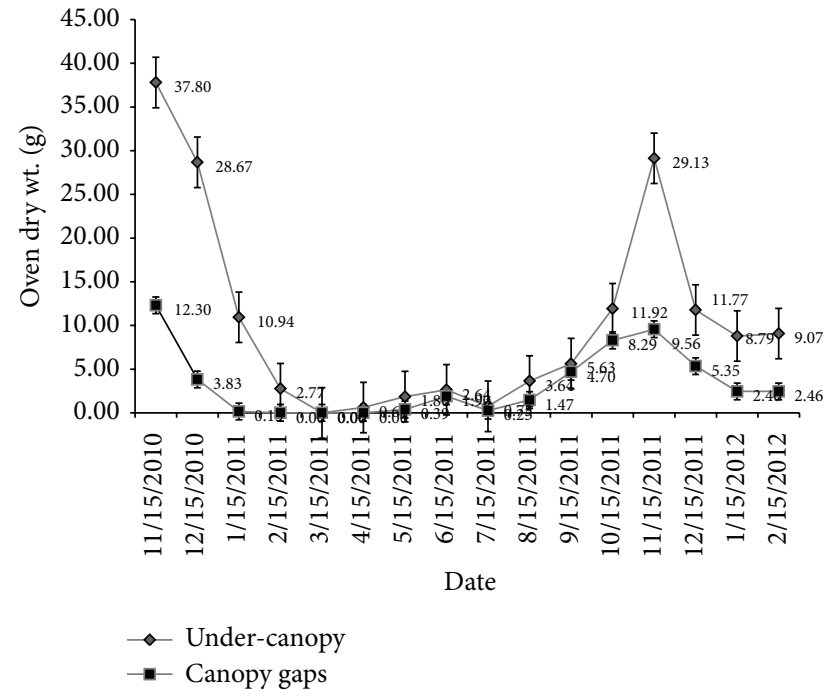

FIGURE 3: Litter fall patterns of S. sebiferum in the marked site.

in under-canopy and $0.38 \mathrm{Mgha}^{-1} \mathrm{y}^{-1}=0.19 \mathrm{t} \mathrm{Cha}^{-1} \mathrm{y}^{-1}$ in canopy gap) (Figure 3). In the month of March, no litter was recorded in the traps placed in both undercanopy and canopy gap. While litter fall recorded a general increasing trend from March to June, litter fall during the month of July decreased drastically (Figure 3). Litter fall then increased up to November after which it saw a steep decline. In general, total litter fall in under-canopy
(4.04 $\mathrm{Mgha}^{-1} \mathrm{y}^{-1}=2.02 \mathrm{tCha}^{-1} \mathrm{y}^{-1}$ ) was higher than in canopy gap (1.87 $\left.\mathrm{Mg} \mathrm{ha}^{-1} \mathrm{y}^{-1}=0.93 \mathrm{t} \mathrm{Cha}^{-1} \mathrm{y}^{-1}\right)$.

Categorization of litter into different components revealed that under-canopy litter had $2.12 \mathrm{Mg} \mathrm{ha}^{-1} \mathrm{y}^{-1}$ of leaf, $0.47 \mathrm{Mg} \mathrm{ha}^{-1} \mathrm{y}^{-1}$ of wood and debris, and $1.44 \mathrm{Mg} \mathrm{ha}^{-1} \mathrm{y}^{-1}$ of inflorescence/seed (Figure 4).

In the canopy gap, leaf fall was $1.08 \mathrm{Mg} \mathrm{ha}^{-1} \mathrm{y}^{-1}$, wood and debris were $0.276 \mathrm{Mgha}^{-1} \mathrm{y}^{-1}$, and inflorescence/seed litter was $0.51 \mathrm{Mg} \mathrm{ha}^{-1} \mathrm{y}^{-1}$ (Figure 5). Leaf fall was maximum between August and December (for under-canopy it was $2.05 \mathrm{Mg} \mathrm{ha}^{-1} \mathrm{y}^{-1}=1.02 \mathrm{t} \mathrm{Cha}^{-1} \mathrm{y}^{-1}$ and for canopy gap it was $1.05 \mathrm{Mgha}^{-1} \mathrm{y}^{-1}=0.52 \mathrm{Cha}^{-1} \mathrm{y}^{-1}$ ). Wood and debris (twig and branches) were maximum between September and February for under-canopy $\left(0.41 \mathrm{Mg} \mathrm{ha}^{-1} \mathrm{y}^{-1}=0.20 \mathrm{C} \mathrm{ha}^{-1} \mathrm{y}^{-1}\right)$ whereas for canopy gap they were maximum during May to December $\left(0.28 \mathrm{Mg} \mathrm{ha}^{-1} \mathrm{y}^{-1}=0.14 \mathrm{Cha}^{-1} \mathrm{y}^{-1}\right)$. Inflorescence, in the litter, was highest between June and July (for under-canopy $0.07 \mathrm{Mgha}^{-1} \mathrm{y}^{-1}=0.039 \mathrm{Cha}^{-1} \mathrm{y}^{-1}$ and for canopy gap $0.067 \mathrm{Mg} \mathrm{ha}^{-1} \mathrm{y}^{-1}=0.033 \mathrm{C} \mathrm{ha}^{-1} \mathrm{y}^{-1}$ ). Seed fall was high between November and January (for undercanopy $0.74 \mathrm{Mg} \mathrm{ha}^{-1} \mathrm{y}^{-1}=0.37 \mathrm{Cha}^{-1} \mathrm{y}^{-1}$ and for canopy gap $0.43 \mathrm{Mg} \mathrm{ha}^{-1} \mathrm{y}^{-1}=0.21 \mathrm{Cha}^{-1} \mathrm{y}^{-1}$ ) (Figures 4 and 5). Litter fall differed significantly between under-canopy and canopy gap $(t=2.3198, P<0.05)$.

3.2. Litter Decomposition. The decomposition pattern of litter is shown in Figure 6. After 181 days, out of the total $10 \mathrm{~g}$, only $1.65 \mathrm{~g}$ litter remained in under-canopy while only $1.31 \mathrm{~g}$ was left in canopy gap. The decomposition rate was $0.46 \%$ day $^{-1}$ 


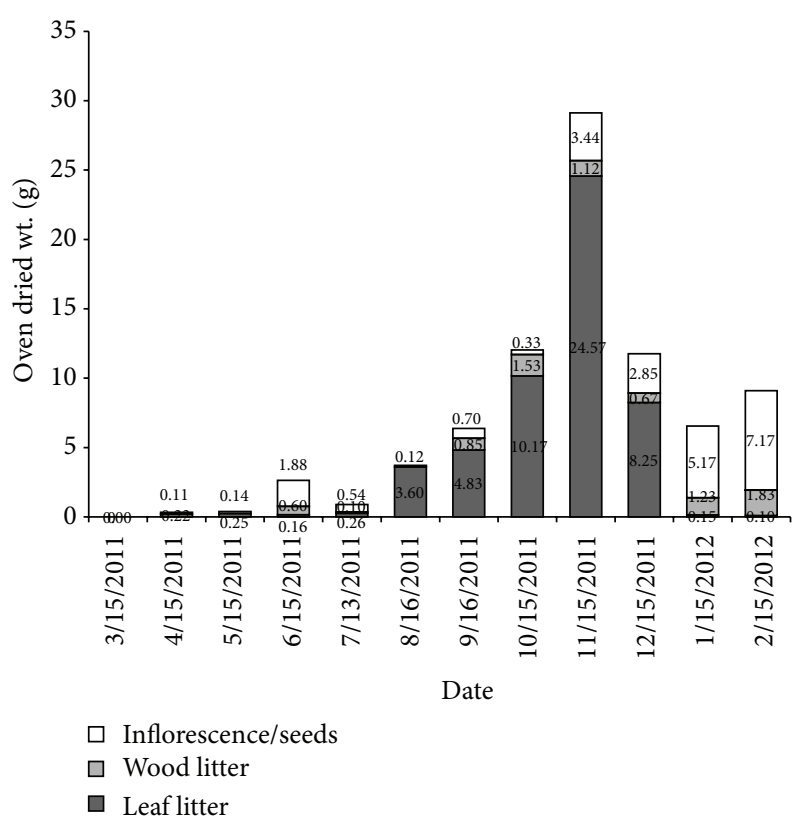

Figure 4: Partitioning of litter into leaf, wood, and inflorescence/seed across different months in under-canopy.

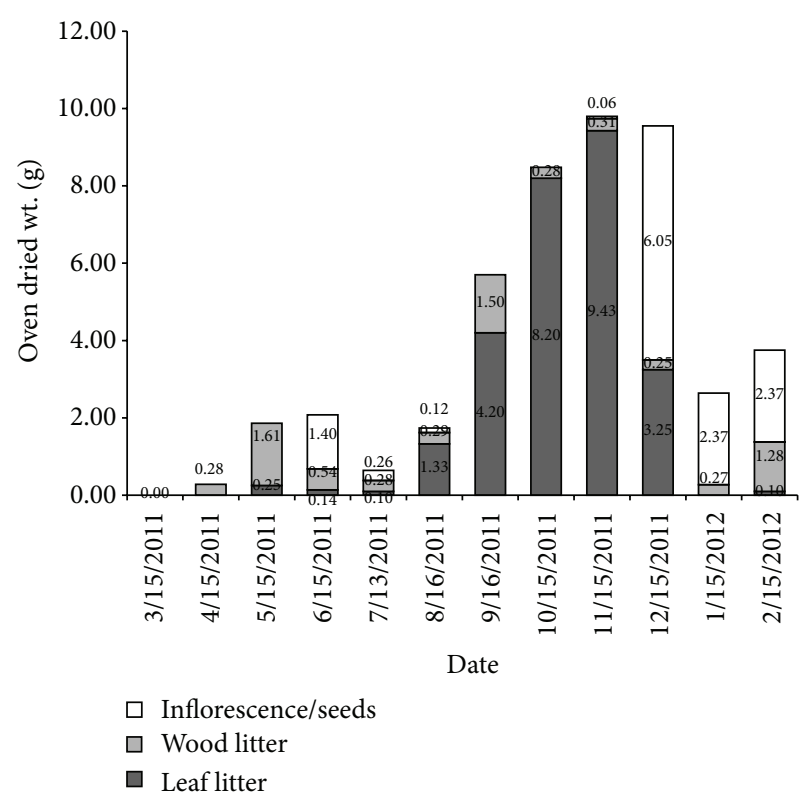

FIgURE 5: Partitioning of litter into leaves, wood, and inflorescence/seed across different months in canopy gap.

in under-canopy and $0.48 \%$ day $^{-1}$ in canopy gap. However, total decomposition at both sites occurred in 196 days. Decomposition of the litter in under-canopy $\left(0.401 \%\right.$ day $\left.^{-1}\right)$ and in canopy gap $\left(0.486 \% \mathrm{day}^{-1}\right)$ was faster between January and March. From late March to May, the decomposition rate was slow $\left(0.242 \%\right.$ day $^{-1}$ in under-canopy and $0.120 \%$ day $^{-1}$ in canopy gap). The rate of decomposition was maximum

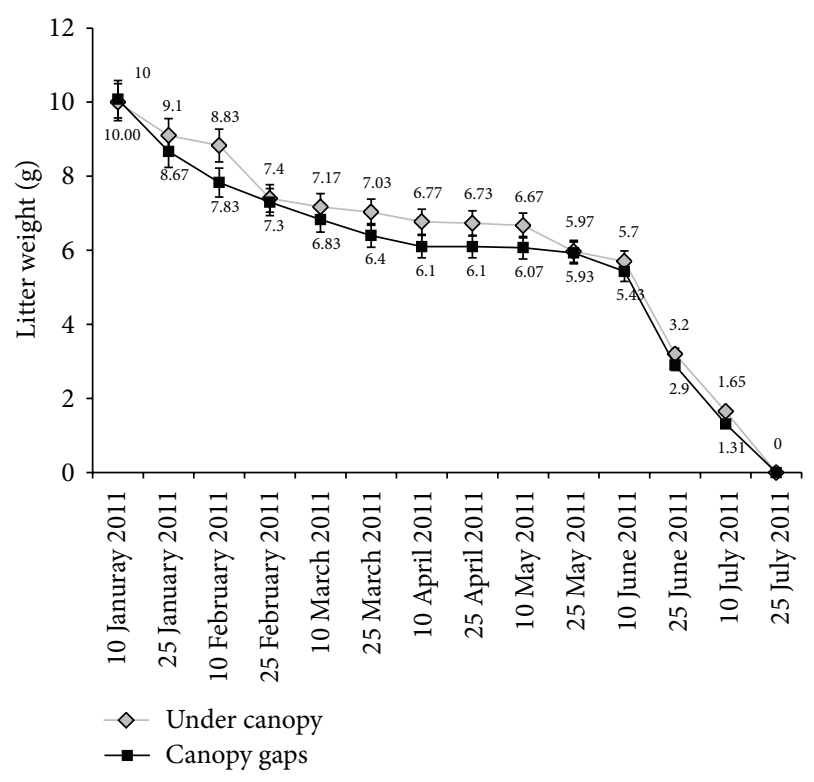

FIGURE 6: Patterns of litter decomposition.

after 25 June in both under-canopy $\left(1.26 \%\right.$ day $\left.^{-1}\right)$ and canopy gap $\left(1.36 \% \mathrm{day}^{-1}\right)$. The decay rate coefficient $(k)$ was 0.009 day $^{-1}\left(3.20 \mathrm{y}^{-1}\right)$ in under-canopy and $0.011 \mathrm{day}^{-1}$ $\left(4.01 \mathrm{y}^{-1}\right)$ in canopy gap. No significant difference in the decomposition rate of $S$. sebiferum in under-canopy and in canopy gap $(t=0.37, P>0.05)$ was found.

\section{Discussion}

High litter fall and its rapid decomposition are important traits of invasive species that affects the biogeochemical cycle and nutrient status of soil $[28,29]$. Litter fall and its decomposition revealed high turnover in $S$. sebiferum. It was $4.04 \mathrm{Mg} \mathrm{ha}^{-1} \mathrm{y}^{-1}\left(2.02 \mathrm{tCha}^{-1} \mathrm{y}^{-1}\right)$ in under-canopy and $1.87 \mathrm{Mg} \mathrm{ha}^{-1} \mathrm{y}^{-1}\left(0.93 \mathrm{tCha}^{-1} \mathrm{y}^{-1}\right)$ in canopy gap. Minimum litter fall was recorded during March. This is because bud bursting and leafing start in the species during this month [23]. Leaf litter production peaked in November. Sapium sebiferum, being a deciduous species, sheds its leaf during winter months. November marks the beginning of winter season in the Himalaya. Late fruiting and maturation of fruits is also a key characteristic of the S. sebiferum [23]. Consequently, seeds that dehisced during November-December showed the maximum fall during January. The litter fall estimates of $S$. sebiferum are comparable to that of native Himalayan species. In Betula utilis dominated forests, litter fall has been reported to be $3.6 \mathrm{tha}^{-1}$, while for Abies pindrow and Acer mixed broadleaf forest the litter fall has been reported to be $2.6 \mathrm{t} \mathrm{ha}^{-1}$ and $2.8 \mathrm{tha}^{-1}$, respectively [30]. Other studies in Western Himalaya, assuming $50 \%$ carbon in dry matter, have reported litter fall to the tune of $1.7 \mathrm{tCha}^{-1} \mathrm{y}^{-1}$ in sal forest [31], $2.1 \mathrm{tCha}^{-1} \mathrm{y}^{-1}$ in chir pine-mixed forest [32], 3.2 $\mathrm{tC} \mathrm{ha}^{-1} \mathrm{y}^{-1}$ in mixed oak-chir pine [32], and $2.8 \mathrm{tCha}^{-1} \mathrm{y}^{-1}$ in mixed oak-conifer forest [33]. Thus, despite being a small statured 
tree, S. sebiferum stand produces litter at par with stands of tree species that are almost double its size. How the changing climatic conditions will affect litter production and decomposition in Sapium sebiferum is a noteworthy area of research. Recent studies on this aspect, owing to changing climatic conditions, have highlighted changes in forest composition and thereby litter production rates [34].

The litter decomposition rate was relatively higher during January and February but lower during March to May (Figure 6). The decay of litter depends on litter composition, decaying organisms, and the environmental conditions [35, 36]. During January-February, winter rains at the study site help in maintaining soil moisture and thereby the activities of soil microorganisms, which help in litter decomposition $\left(0.401 \%\right.$ day $\left.^{-1}\right)$. During May, the ambient temperature rises in Himalaya and the rainfall decreases. Also, during dry spell, soil fauna moves deeper into the soil [37], which possibly limits the activity of microorganisms on the soil surface and ultimately causes reduction in the rate of decomposition $(0.242 \%$ day $^{-1}$ ). In temperate arid lands of Southern Hemisphere high temperature has been reported to limit the activities of soil microorganisms and thereby litter decomposition [38].

The rainy season after June 15 and congenial temperature conditions lead to increased microbial activity and consequently higher litter decomposition rates $\left(1.26 \%\right.$ day $\left.^{-1}\right)$. Further, during the initial phases, the soluble compounds in litter (sugars, phenolics, hydrocarbons, and glycerides) degrade fast and hence litter decomposition rates are relatively higher [1]. Lignified tissues decompose at a slower rate and hence decomposition rates are lower during later stages [1]. It has been reported that, as opposed to biotic degradation, decomposition of lignin is more photo-dependent [6].

In general, decomposition rate of $S$. sebiferum litter is higher than some of the native species of Himalaya such as Lyonia ovalifolia $\left(0.253 \%\right.$ day $\left.^{-1}\right)$, Mallotus philippensis $\left(0.274 \%\right.$ day $\left.^{-1}\right)$, Shorea robusta $\left(0.253 \%\right.$ day $\left.^{-1}\right)$ [39], Quercus floribunda $\left(0.193 \%\right.$ day $\left.^{-1}\right)$, Q. leucotrichophora $\left(0.183 \%\right.$ day $\left.^{-1}\right)$ [40], and Q. glauca $\left(0.274 \%\right.$ day $\left.^{-1}\right)$. The decay rate coefficient $(k)$ of S. sebiferum was 0.009 day $^{-1}\left(3.20 \mathrm{y}^{-1}\right)$ in under-canopy and 0.011 day $^{-1}\left(4.01 \mathrm{y}^{-1}\right)$ in canopy gap. These values are close to $4.33 \mathrm{y}^{-1}$ reported by Cameron and Spencer [15] for $S$. sebiferum in USA. Petersen and Cummins [41] have classified decay rate coefficient into "fast" $(k>0.01)$, "medium" $(k=0.005-0.01)$, and "slow" $(k<0.005)$ categories. Based on this, it can be said that decay of S. sebiferum leaf litter is rapid. Though the present study did not look into the nutrient dynamics, rapid decay of $S$. sebiferum leaves has led to changes in soil $\mathrm{Ca}, \mathrm{N}, \mathrm{K}, \mathrm{Mg}$, and $\mathrm{S}$ concentration in other parts of the globe $[15,42,43]$. Tree species are known to alter the forest litter decomposition through long term plant soil interactions [44-46]. Faster decay of S. sebiferum litter is also known to result in eutrophication [47] and release of allelochemicals $[48,49]$ that help in self-facilitation of the species. Long term experiments on soil enzyme activity and Sapium sebiferum litter inputs are desired. Such experiments as a part of Detritus Input and Removal Treatments in Hungary have provided valuable insights into how the enzyme activity in soil is influenced by the quality and quantity of litter [50].

\section{Conclusions}

The present study concludes that Sapium sebiferum produces high amount of litter that decays rapidly. This renders the species capable of modifying habitats to its advantage.

\section{Conflict of Interests}

The authors declare that there is no conflict of interests regarding the publication of this paper.

\section{Acknowledgments}

The authors are thankful to the Director CSIR-IHBT Palampur for the facilities and support. Faculty and members of Biodiversity Division are acknowledged for their comments and valuable help. Constructive comments of the editor and the three anonymous reviewers helped in improving the earlier version of the paper. Vikrant Jaryan thanks CSIR for grant of SRF. Additional funding for the work was provided through Project BSC-0106 of the Council of Scientific and Industrial Research. This is IHBT communication no. 3713.

\section{References}

[1] B. Berg and C. McClaugherty, Plant Litter, Springer, Berlin, Germany, 2nd edition, 2003.

[2] R. Haase, "Litterfall and nutrient return in seasonally flooded and non-flooded forest of the Pantanal, Mato Grosso, Brazil," Forest Ecology and Management, vol. 117, no. 1-3, pp. 129-147, 1999.

[3] X. N. Xu and E. Hirata, "Forest floor mass and litterfall in Pinus luchuensis plantations with and without broad-leaved trees," Forest Ecology and Management, vol. 157, no. 1-3, pp. 165-173, 2002.

[4] W. H. van der Putten, R. D. Bardgett, J. D. Bever et al., "Plant-soil feedbacks: The past, the present and future challenges," Journal of Ecology, vol. 101, no. 2, pp. 265-276, 2013.

[5] R. H. Waring and W. H. Schlesinger, Forest Ecosystem: Concepts and Management, Academic Press, New York, NY, USA, 1985.

[6] A. T. Austin and C. L. Ballaré, "Dual role of lignin in plant litter decomposition in terrestrial ecosystems," Proceedings of the National Academy of Sciences of the United States of America, vol. 107, no. 10, pp. 4618-4622, 2010.

[7] A. T. Austin, P. I. Araujo, and P. E. Leva, "Interaction of position, litter type, and water pulses on decomposition of grasses from the semiarid Patagonian steppe," Ecology, vol. 90, no. 9, pp. 2642-2647, 2009.

[8] J. G. Ehrenfeld, "Effects of exotic plant invasions on soil nutrient cycling processes," Ecosystems, vol. 6, no. 6, pp. 503-523, 2003.

[9] J. D. Weidenhamer and R. M. Callaway, "Direct and indirect effects of invasive plants on soil chemistry and ecosystem function," Journal of Chemical Ecology, vol. 36, no. 1, pp. 59-69, 2010.

[10] J. Kao-Kniffin and T. C. Balser, "Soil fertility and the impact of exotic invasion on microbial communities in Hawaiian forests," Microbial Ecology, vol. 56, no. 1, pp. 55-63, 2008.

[11] R. K. Didham, J. M. Tylianakis, N. J. Gemmell, T. A. Rand, and R. M. Ewers, "Interactive effects of habitat modification and 
species invasion on native species decline," Trends in Ecology and Evolution, vol. 22, no. 9, pp. 489-496, 2007.

[12] B. Gooden, K. French, P. J. Turner, and P. O. Downey, "Impact threshold for an alien plant invader, Lantana camara L., on native plant communities," Biological Conservation, vol. 142, no. 11, pp. 2631-2641, 2009.

[13] P. M. Vitousek, L. R. Walker, L. D. Whiteaker, D. MuellerDombois, and P. A. Matson, "Biological invasion by Myrica faya alters ecosystem development in Hawaii," Science, vol. 238, no. 4828, pp. 802-804, 1987.

[14] I. W. Ashton, L. A. Hyatt, K. M. Howe, J. Gurevitch, and M. T. Lerdau, "Invasive species accelerate decomposition and litter nitrogen loss in a mixed deciduous forest," Ecological Applications, vol. 15, no. 4, pp. 1263-1272, 2005.

[15] G. N. Cameron and S. R. Spencer, "Rapid leaf decay and nutrient release in a Chinese tallow forest," Oecologia, vol. 80, no. 2, pp. 222-228, 1989.

[16] K. N. Suding, W. Stanley Harpole, T. Fukami et al., "Consequences of plant-soil feedbacks in invasion," Journal of Ecology, vol. 101, no. 2, pp. 298-308, 2013.

[17] V. Jaryan, S. K. Uniyal, A. Kumar, R. C. Gupta, O. Parkash, and R. D. Singh, "Distribution characteristics of Sapium sebiferum (L.) Roxb. An invasive tree species in Himachal Pradesh, Western Himalaya," Proceedings of Indian National Science Academy, vol. 79, pp. 215-234, 2013.

[18] S. Sharma, H. C. Rikhari, and L. M. S. Palni, "Adoption of a potential plantation tree crop as an agroforestry species but for the wrong reasons: a case study of the Chinese tallow tree from central Himalaya," International Tree Crops Journal, vol. 9, no. 1, pp. 37-45, 1996.

[19] R. N. Parker, A Forest Flora for Punjab with Hazara and Delhi. Reprint, Bedi Printing Press, Dehradun, India, 1984.

[20] USDA, The PLANTS Database, National Plant Data Center, Baton Rouge, La, USA, 1999, http://plants.usda.gov/java/.

[21] J. R. Hosking, B. J. Conn, and B. J. Lepschi, "Plant species first recognized as naturalized for New South Wales over the period 2000-2001," Cunninghamia, vol. 8, pp. 175-187, 2003.

[22] V. Jaryan, A. Datta, S. K. Uniyal, A. Kumar, R. C. Gupta, and R. D. Singh, "Modelling potential distribution of Sapium sebiferum - an invasive tree species in western Himalaya," Current Science, vol. 105, no. 9, pp. 1282-1287, 2013.

[23] V. Jaryan, S. K. Uniyal, R. C. Gupta, and R. D. Singh, "Phenological documentation of an invasive species, Sapium sebiferum (L.) Roxb," Environmental Monitoring and Assessment, vol. 186, pp. 4423-4429, 2014.

[24] J. S. Singh and S. P. Singh, "Forest vegetation of the Himalaya," The Botanical Review, vol. 53, no. 1, pp. 80-192, 1987.

[25] J. S. Olson, "Energy stores and the balance of producers and decomposers in ecological systems," Ecology, vol. 44, pp. 322331, 1963.

[26] R. K. Wieder and G. E. Lang, "A critique of the analytical methods used in examining decomposition data obtained from litter bags," Ecology, vol. 63, no. 6, pp. 1636-1642, 1982.

[27] W. L. Silver and R. K. Miya, "Global patterns in root decomposition: comparisons of climate and litter quality effects," Oecologia, vol. 129, no. 3, pp. 407-419, 2001.

[28] A. Martınez-Yrızar, "Biomass distribution and primary productivity of tropical dry forests," in Seasonally Dry Tropical Forests, S. H. Bullock, H. A. Mooney, and E. Medina, Eds., pp. 326-345, Cambridge University Press, Cambridge, Mass, USA, 1995.
[29] J. L. Herbohn and R. A. Congdon, "Ecosystem dynamics at disturbed and undisturbed sites in North Queensland wet tropical rain forest. III. Nutrient returns to the forest floor through litterfall," Journal of Tropical Ecology, vol. 14, no. 2, pp. 217-229, 1998.

[30] S. Gairola, R. S. Rawal, and U. Dhar, "Patterns of litterfall and return of nutrients across anthropogenic disturbance gradients in three subalpine forests of West Himalaya, India," Journal of Forest Research, vol. 14, no. 2, pp. 73-80, 2009.

[31] R. P. Shukla and P. S. Ramakrishnan, "Phenology of trees in a sub-tropical humid forest in north-eastern India," Vegetatio, vol. 49, no. 2, pp. 103-109, 1982.

[32] M. S. Mehra, P. C. Pathak, and J. S. Singh, "Nutrient movement in litter fall and precipitation components for certain forests of Kumaun Himalaya," Tropical Plant Science Research, vol. 1, pp. 175-180, 1985.

[33] A. N. Pandey and J. S. Singh, "A quantitative study of the forest floor, litter fall and nutrient return in as oak-conifer forest in Himalaya. Composition and dynamics of forest floor," Oecologia, vol. 2, pp. 49-61, 1981.

[34] Z. Kotroczó, Z. Veres, I. Fekete, M. Papp, and J. A. Tóth, "Effects of climate change on litter production in a Quercetum petraeaecerris forest in Hungary," Acta Silvatica et Lignaria Hungarica, vol. 8, no. 1, pp. 31-38, 2012.

[35] V. Meentemeyer, "The geography of organic decomposition rates," Annals of the Association of American Geographers, vol. 74, no. 4, pp. 551-560, 1984.

[36] M.-M. Coûteaux, P. Bottner, and B. Berg, "Litter decomposition climate and litter quality," Trends in Ecology and Evolution, vol. 10, no. 2, pp. 63-66, 1995.

[37] D. P. Trueba, M. M. V. González, and C. R. Aragonés, “Comunidades de la mesofauna edáfica en una selva baja inundable de la reserva de la Biósfera de Sian Kaan, Quintana Roo, México," Revista de Biologia Tropical, vol. 47, no. 3, pp. 489-492, 1999.

[38] P. I. Araujo, L. Yahdjian, and A. T. Austin, "Do soil organisms affect aboveground litter decomposition in the semiarid Patagonian steppe, Argentina?" Oecologia, vol. 168, no. 1, pp. 221-230, 2012.

[39] J. S. Singh and S. P. Singh, "An integrated ecological study of eastern Kumaun Himalaya, with emphasis on natural resources. Vol 2. Site specific studies," Final Report (HCS/DST/187/76), Kumaun University, Nainital, India, 1984.

[40] U. Pandey and J. S. Singh, "Leaf-litter decomposition in an oakconifer forest in himalaya: the effects of climate and chemical composition," Forestry, vol. 55, no. 1, pp. 47-59, 1982.

[41] R. C. Petersen and K. W. Cummins, "Leaf processing in a woodland stream," Freshwater Biology, vol. 4, pp. 343-368, 1974.

[42] K. A. Bruce, G. N. Cameron, and P. A. Harcombe, "Initiation of a new woodland type on the Texas coastal prairie by the Chinese tallow tree (Sapium sebiferum (L.) Roxb.)," Bulletin of the Torrey Botanical Club, vol. 122, no. 3, pp. 215-225, 1995.

[43] K. A. Bruce, G. N. Cameron, P. A. Harcombe, and G. Jubinsky, "Introduction, impact on native habitats, and management of a woody invader, the Chinese tallow tree, Sapium sebiferum (L.) Roxb," Natural Areas Journal, vol. 17, no. 3, pp. 255-260, 1997.

[44] L. Vivanco and A. T. Austin, "Tree species identity alters forest litter decomposition through long-term plant and soil interactions in Patagonia, Argentina," Journal of Ecology, vol. 96, no. 4, pp. 727-736, 2008.

[45] P. Castro-Díez, N. González-Muñoz, A. Alonso, A. Gallardo, and L. Poorter, "Effects of exotic invasive trees on nitrogen 
cycling: a case study in Central Spain," Biological Invasions, vol. 11, no. 8, pp. 1973-1986, 2009.

[46] J. H. C. Cornelissen and W. K. Cornwell, "The tree of life in ecosystems: evolution of plant effects on carbon and nutrient cycling," Journal of Ecology, vol. 102, no. 2, pp. 269-274, 2014.

[47] G. Jubinsky, “Chinese tallow gets worse!," The Palmetto, vol. 13, no. 3, pp. 1-3, 1993.

[48] C. A. Gresham, "Potential allelopathic interactions of Sapium sebiferum on loblolly pine germination and seedling growth," Proceedings of the Fourth Biennial Southern Silvicultural Research Conference United States Forest Service General Technical Report SE-42, 1986.

[49] W. C. Conway, L. M. Smith, and J. F. Bergan, "Potential allelopathic interference by the exotic Chinese tallow tree (Sapium sebiferum)," American Midland Naturalist, vol. 148, no. 1, pp. 4353, 2002.

[50] Z. Kotroczó, Z. Veres, I. Fekete et al., "Soil enzyme activity in response to long-term organic matter manipulation," Soil Biology \& Biochemistry, vol. 70, pp. 237-243, 2014. 

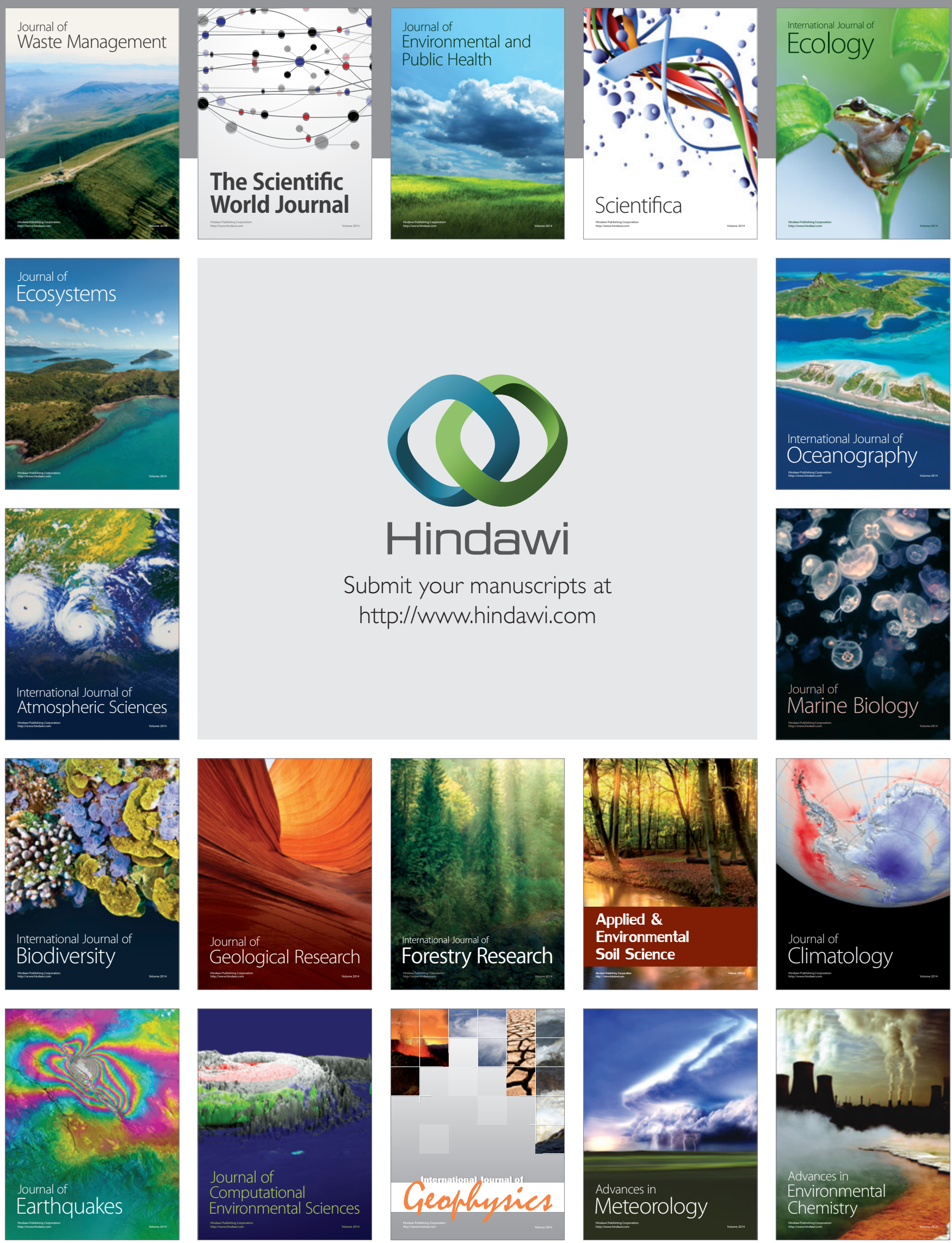